\title{
Enhanced disinfection of Escherichia coli and bacteriophage MS2 in water using a copper and silver loaded titanium dioxide nanowire membrane
}

\author{
Guiying RAO ${ }^{1}$, Kristen S. BRASTAD ${ }^{2,3}$, Qianyi ZHANG ${ }^{2}$, Rebecca ROBINSON ${ }^{3}$, Zhen HE$^{4}$, Ying LI (ه) ${ }^{1}$ \\ 1 Department of Mechanical Engineering, Texas A\&M University, College Station, TX 77843, USA \\ 2 Department of Mechanical Engineering, University of Wisconsin-Milwaukee, Milwaukee, WI 53211, USA \\ 3 A.O. Smith Corporate Technology Center, Milwaukee, WI 53224, USA \\ 4 Department of Civil and Environmental Engineering, Virginia Polytechnic Institute and State University, Blacksburg, VA 24061, USA
}

\section{H I G H L I G H T S}

- A novel photocatalytic $\mathrm{Ag}-\mathrm{Cu}-\mathrm{TiO}_{2}$ nanowire membrane was fabricated.

- Bacteria and virus disinfection was improved by co-depositing $\mathrm{Ag}$ and $\mathrm{Cu}$ onto membrane.

- Synergetic photocatalytic effects and free metal ions of $\mathrm{Ag}$ and $\mathrm{Cu}$ contribute to disinfection.

- $7.68 \log$ removal of E. coli and $4.02 \log$ removal of bacteriophage MS2 were achieved.

\section{A R T I C L E I N F O}

Article history:

Received 28 January 2016

Received in revised from 8 April 2016

Accepted 10 May 2016

\section{Keywords:}

Photo-activated disinfection

Titanium dioxide

Nanowire membrane

Silver

Copper

\section{GR A P H I C A B T R A C T}

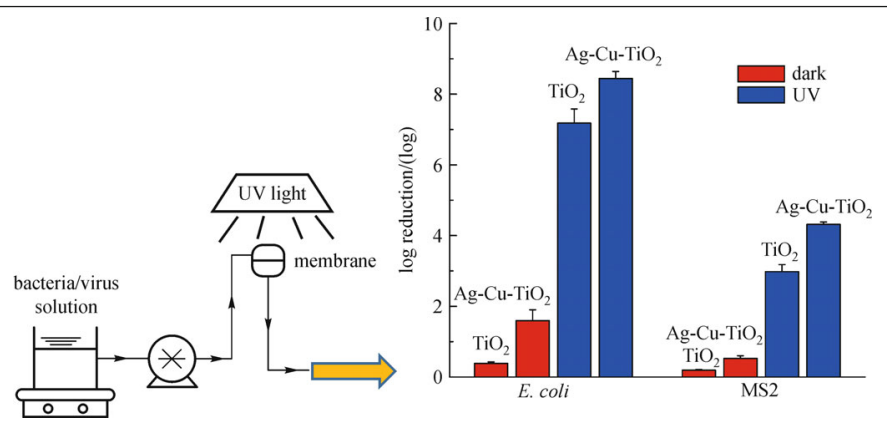

A B S T R A C T

Titanium dioxide $\left(\mathrm{TiO}_{2}\right)$ is a widely used photocatalyst that has been demonstrated for microorganism disinfection in drinking water. In this study, a new material with a novel structure, silver and copper loaded $\mathrm{TiO}_{2}$ nanowire membrane $\left(\mathrm{Cu}-\mathrm{Ag}-\mathrm{TiO}_{2}\right)$ was prepared and evaluated for its efficiency to inactivate $E$. coli and bacteriophage MS2. Enhanced photo-activated bactericidal and virucidal activities were obtained by the $\mathrm{Cu}-\mathrm{Ag}-\mathrm{TiO}_{2}$ membrane than by the $\mathrm{TiO}_{2}, \mathrm{Ag}-\mathrm{TiO}_{2}$ and $\mathrm{Cu}-\mathrm{TiO}_{2}$ membranes under both dark and UV light illumination. The better performance was attributed to the synergies of enhanced membrane photoactivity by loading silver and copper on the membrane and the synergistic effect between the free silver and copper ions in water. At the end of a $30 \mathrm{~min}$ test of deadend filtration under $254 \mathrm{~nm}$ UV irradiation, the $\mathrm{Cu}-\mathrm{Ag}-\mathrm{TiO}_{2}$ membrane was able to obtain an E. coli removal of $7.68 \mathrm{log}$ and bacteriophage MS2 removal of $4.02 \mathrm{log}$, which have met the US EPA standard. The free metal ions coming off the membrane have concentrations of less than $10 \mathrm{ppb}$ in the water effluent, far below the US EPA maximum contaminant level for silver and copper ions in drinking water. Therefore, the photo-activated disinfection by the $\mathrm{Cu}-\mathrm{Ag}-\mathrm{TiO}_{2}$ membrane is a viable technique for meeting drinking water treatment standards of microbiological water purifiers.

(C) Higher Education Press and Springer-Verlag Berlin Heidelberg 2016

\section{Introduction}

Microbial contamination of drinking water frequently occurs due to fecal matter from sewage discharges, leaking septic tanks, and runoff from animal feedlots into water bodies. Chlorine and ozone type disinfectants can

$凶$ Corresponding author

E-mail: yingli@tamu.edu effectively inactivate microorganisms but disinfection byproducts (DBPs) are detected in water which have potential carcinogenic effects on humans $[1,2]$. The concern of formation of DBPs leads to considerable interest in alternate disinfection technologies such as the photo-activated processes, which have shown enhanced disinfection capabilities since 1988 [3]. In photo-activated processes, the generation of the highly reactive hydroxyl radicals (e.g., $\mathrm{OH} \cdot$ ) or reactive oxygen species (ROS) by UV light irradiation can cause oxidative stress damage to 
cell membranes and effectively inactivate microorganisms [4]. Titanium dioxide $\left(\mathrm{TiO}_{2}\right)$ is a most studied photocatalyst because it is inexpensive, abundant, corrosionresistant and produces no dangerous DBPs [5]. Despite the numerous advantages, $\mathrm{TiO}_{2}$ suffers from the fast recombination of photo-generated electron-hole pairs [6]. Therefore, loading metal ions such as silver and copper onto photocatalysts was carried out to increase the activity of the photocatalyst by separating the electrons and holes more effectively [7-9]. Silver and copper were also recognized for their antimicrobial effects $[8,10]$ and the antibacterial capabilities of $\mathrm{Ag}-\mathrm{TiO}_{2}$ nanoparticles and $\mathrm{Cu}$ $\mathrm{TiO}_{2}$ nanoparticles under UV illumination have been studied previously $[7,11]$. However, the virucidal properties of the metal-ion deposited $\mathrm{TiO}_{2}$ was seldom examined $[12,13]$, hampering the development of commercially viable applications of photocatalysts such as for drinking water treatment. In addition, the combination of silver and copper together with $\mathrm{TiO}_{2}$ nanowires remains largely unexplored for its antimicrobial properties, although the combined metal loading of $\mathrm{TiO}_{2}$ nanoparticles have been recently studied for the removal of organic contaminants from water $[14,15]$.

This study experimentally established the individual and combined effects of silver and copper loaded $\mathrm{TiO}_{2}$ nanowire membrane on the inactivation of bacteria and virus. Escherichia coli (E. coli) was used as the model bacteria that is also frequently used in the literature for bacterial inactivation study $[10,11,16]$. It is relatively more UV resistant [17] and is a typical biologic indicator of water disinfection quality [18]. Bacteriophage MS2 was used as a model virus because of its simplicity to propagate and enumerate, similarity to many waterborne pathogenic viruses, and more resistance to UV disinfection than other bacteriophages [13]. Bacteriophage MS2 has also been frequently reported as a model virus for viral inactivation studies in the literature $[13,19,20]$. Unlike the traditional methods of using particulate and colloidal $\mathrm{TiO}_{2}$ suspensions, which shield the UV light transmission and have difficulties for separation and reuse of the photocatalysts, the $\mathrm{TiO}_{2}$ membrane is a relatively new form of the catalyst. It allows reuse of the material and combines the photocatalysis mechanism for organic degradation and microbial inactivation with the physical separation of membrane filtration into a single reactor [21].

\section{Experimental}

\subsection{Membrane preparation}

The photocatalytic membranes were fabricated in a twostep procedure. First the $\mathrm{TiO}_{2}$ nanowires were prepared through a hydrothermal process, and then metal species were added through photodeposition for silver and through adsorption for copper. To make the $\mathrm{TiO}_{2}$ nanowires, $1 \mathrm{~g}$ of
$\mathrm{TiO}_{2}$ P25 nanopowders (Sigma-Aldrich, St. Louis, MO, USA), $65 \mathrm{~mL}$ of $10 \mathrm{M} \mathrm{NaOH}$ (Sigma-Aldrich, St. Louis, MO, USA) and $65 \mathrm{~mL}$ of ethanol (Sigma-Aldrich, St. Louis, MO, USA) were mixed together inside a PTFE lined autoclave at $160^{\circ} \mathrm{C}$ for $12 \mathrm{~h}$. The resulting white gel was then washed with $0.1 \mathrm{M} \mathrm{HCl}$ and deionized water alternatively until $\mathrm{pH}$ 7. The $\mathrm{TiO}_{2}$ nanowires were then suspended in deionized water with a total volume of $500 \mathrm{~mL}$. To prepare the $\mathrm{TiO}_{2}$ membrane, $50 \mathrm{~mL}$ of the $\mathrm{TiO}_{2}$ nanowire suspension was sonicated for $15 \mathrm{~min}$ in a sonicator (FB505, Fisher Scientific, Pittsburgh, PA, USA) and then vacuum filtered onto a $47 \mathrm{~mm}$ diameter fiberglass substrate. A uniformly distributed layer was observed on the substrate surface. The membrane was air-dried overnight and calcined at $375^{\circ} \mathrm{C}$ for $12 \mathrm{~h}$.

To photo-deposit silver onto $\mathrm{TiO}_{2}$ nanowires, $3 \mathrm{M} \mathrm{HNO}_{3}$ was first added into $50 \mathrm{~mL}$ of the $\mathrm{TiO}_{2}$ nanowire suspension to reach pH 3. Next, $\mathrm{AgNO}_{3}$ (Sigma-Aldrich, St. Louis, MO, USA) was added into the suspension with a silver to $\mathrm{TiO}_{2}$ atomic ratio of $2 \%$, which is an optimum ratio identified by prior work [22]. Finally, $2 \mathrm{~mL}$ of $2.5 \%$ $\mathrm{HClO}_{4}$ solution (Sigma-Aldrich, St. Louis, MO, USA) was added to the suspension and the solution was mixed continuously under UV irradiation $(\lambda=365 \mathrm{~nm}$, UVP LLC, Upland, CA, USA) for $3 \mathrm{~h}$. A dark gray color was observed at the end, suggesting the successful deposition of silver onto the $\mathrm{TiO}_{2}$ nanowires. The $\mathrm{Ag}-\mathrm{TiO}_{2}$ membrane was prepared via the same vacuum filtration and calcination methods for the $\mathrm{TiO}_{2}$ membrane preparation.

The adsorption of copper ions onto the $\mathrm{TiO}_{2}$ and $\mathrm{Ag}$ $\mathrm{TiO}_{2}$ nanowires was achieved by mixing the $\mathrm{TiO}_{2}$ suspension and the $\mathrm{Ag}-\mathrm{TiO}_{2}$ suspension (after photodeposition) with $\mathrm{Cu}\left(\mathrm{NO}_{3}\right)_{2}$ solution (Sigma-Aldrich, St. Louis, MO, USA). The optimal copper to $\mathrm{TiO}_{2}$ atomic ratio was selected as $3 \%$, which is the optimum ratio identified by the prior research [23]. The solution was shaken on an orbital shaker (IKA ${ }^{\circledR}$ Works, Inc., NC, USA) for $16 \mathrm{~h}$ and the copper loaded membranes were prepared using the same method for the $\mathrm{TiO}_{2}$ membrane preparation.

\subsection{Membrane surface morphology and characterization}

The membrane pore size was estimated by analyzing the pore size distribution using a mercury porosimetry method [24]. The membrane surface morphology was evaluated through scanning electron microscopy coupled with energy dispersive spectroscopy (SEM-EDS; Hitachi S570, Tokyo, Japan). The presence of loaded metals and the actual concentrations of metal attached to the $\mathrm{TiO}_{2}$ nanowires were confirmed by EDS analysis (Oxford Instruments, UK) and atomic elemental analysis via inductively coupled plasma mass spectrometry (ICP-MS; Agilent Technologies, CA, USA), respectively. Briefly, the $\mathrm{Ag}-\mathrm{TiO}_{2}, \mathrm{Cu}-\mathrm{TiO}_{2}$, and $\mathrm{Cu}-\mathrm{Ag}-\mathrm{TiO}_{2}$ solutions was each vacuum filtered onto a Pall $0.45 \mu \mathrm{m}$ GN-6 filter paper, which was then placed into a beaker containing $60 \mathrm{~mL}$ of 
nitric acid solution and was heated to just below boiling. After that, the solution was centrifuged and the supernatant was analyzed using ICP-MS.

\subsection{Preparation of the microbial challenge solutions}

To prepare the $E$. coli challenge water, $8.0 \mathrm{~g}$ lysogeny broth (LB Broth) was added into $400 \mathrm{~mL}$ of Type III deionized water in an autoclavable bottle and was gently heated until boiling. The solution was then autoclaved at $121^{\circ} \mathrm{C}$ for $60 \mathrm{~min}$ to obtain the sterilized broth solution. After cooling to room temperature, a loop of freeze-dried E. coli $\left(\mathrm{ATCC}^{\mathbb{B}}\right.$ $11303^{\mathrm{TM}}$ ) was inoculated into the solution, which was then shaken at $130 \mathrm{r} \cdot \mathrm{min}^{-1}$ on an incubated shaker at $35^{\circ} \mathrm{C}$ for $18 \mathrm{~h}$. Next, the solution was centrifuged at $6000 \times \mathrm{g}$ for 5 min and the supernatant was poured off and replaced with $50 \mathrm{~mL}$ of Type III deionized water.

The bacteriophage MS2 that has a similar activity of enteric viruses was prepared in the following manner. First, 5-8 $\mathrm{mL}$ of the sterilized broth solution was poured into a sterile test tube and inoculated with a loopful of freezedried bacteriophage MS2 (ATCC $\AA$ 15597-B1 ${ }^{\mathrm{TM}}$ ), which $(1 \mathrm{~mL})$ was then pipetted into a sterile test tube with 5$8 \mathrm{~mL}$ of an agar solution. The agar solution was prepared by mixing $4.0 \mathrm{~g}$ tryptone, $3.2 \mathrm{~g}$ sea salt, $0.4 \mathrm{~g}$ yeast extract, and $3.2 \mathrm{~g}$ agar with $400 \mathrm{~mL}$ of Type III deionized water in an autoclavable bottle and heated to a boiling followed by autoclaved at $121^{\circ} \mathrm{C}$ for $60 \mathrm{~min}$. The mixture inside the test tube was then poured onto a solidified layer surface in a plate. The solidified layer was prepared by pouring $5-8 \mathrm{~mL}$ of the agar solution in an autoclavable bottle and was autoclaved at $121^{\circ} \mathrm{C}$ for $60 \mathrm{~min}$. After the entire solidification, the plate was inverted and stored in an incubator at $35^{\circ} \mathrm{C}$ for $18 \mathrm{~h}$. Next $8 \mathrm{~mL}$ of sterile $10 \%$ phosphate buffer saline (PBS) solution, the stock solution of which was prepared by dissolving $80 \mathrm{~g} \mathrm{NaCl}, 2 \mathrm{~g}$ $\mathrm{KH}_{2} \mathrm{PO}_{4}, 29 \mathrm{~g} \mathrm{Na}_{2} \mathrm{HPO}_{4} \cdot 12 \mathrm{H}_{2} \mathrm{O}$ and $2 \mathrm{~g} \mathrm{KCl}$ in Type III deionized water to a final volume of $1 \mathrm{~L}$ and autoclaved at $121^{\circ} \mathrm{C}$ for $60 \mathrm{~min}$, was pipetted onto the plate that contains the bacteriophage MS2. The plate was then placed back into the incubator at $35^{\circ} \mathrm{C}$. After $20 \mathrm{~min}$, the PBS solution was centrifuged at $6000 \times \mathrm{g}$ for $5 \mathrm{~min}$ and the supernatant was passed through a $0.45 \mu \mathrm{m}$ syringe filter. The filtered liquid was labeled as the MS2 stock solution and was placed in a refrigerator at $4^{\circ} \mathrm{C}$ for storage.

\subsection{Photo-activated disinfection test setup}

The bench-scale photo-activated disinfection apparatus is shown in Fig. 1. The challenge solution containing microorganisms was continuously pumped into an acrylic membrane holder by a peristaltic pump (Masterflex L/S 7523-80, Vernon Hills, IL, USA) with a flow rate of $5 \mathrm{~mL} \cdot \mathrm{min}^{-1}$, corresponding to a membrane flux of $173 \mathrm{~L} \cdot \mathrm{m}^{-2} \cdot \mathrm{h}^{-1}$. Each experiment lasted for $30 \mathrm{~min}$ and samples were taken every $10 \mathrm{~min}$ to estimate the rejection of microorganism. The $\mathrm{TiO}_{2}$ membrane, $\mathrm{Ag}-\mathrm{TiO}_{2}$ membrane, $\mathrm{Cu}-\mathrm{TiO}_{2}$ membrane, and $\mathrm{Cu}-\mathrm{Ag}-\mathrm{TiO}_{2}$ membranes were tested under both UV light irradiation $(\lambda=254 \mathrm{~nm}$, $11 \mathrm{~W}$, Phillips, NJ, USA) and dark conditions, each test being repeated in triplicate. The challenge solution contained $10^{7} \mathrm{CFU} \cdot \mathrm{mL}^{-1}$ of E. coli or $10^{5} \mathrm{PFU} \cdot \mathrm{mL}^{-1}$ of bacteriophage MS2. The amount of bacteria in water was determined by the heterotrophic plate counts with a pour plate method using USEPA Method 9215. The amount of virus was determined by a double-layer pour plate method. The final log removal of each filter was determined by dividing the concentration of bacteria or viruses in treated

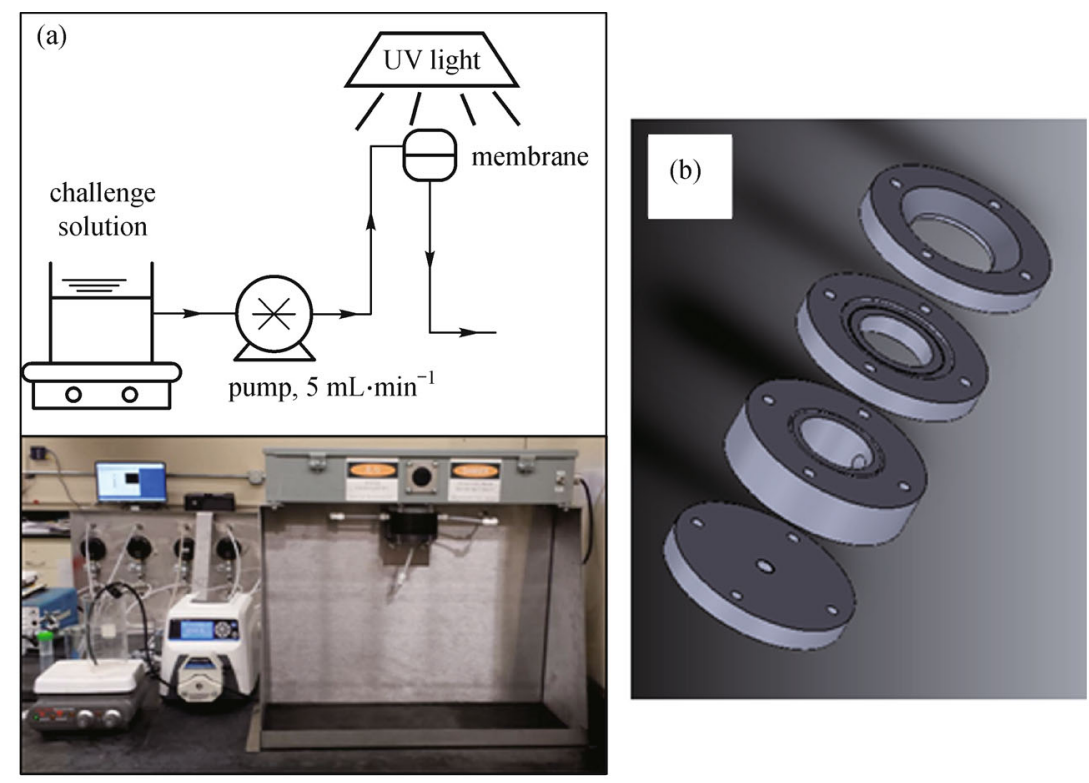

Fig. 1 Schematic of the test setup (a) and the exploded diagram of the membrane holder (b) 
water $\left(N_{\text {out }}\right)$ by the concentration in the feed water $\left(N_{\text {in }}\right)$ :

$$
\log _{\text {removal }}=-\log _{10}\left(\frac{N_{\text {out }}}{N_{\text {in }}}\right),
$$

The concentrations of free metal ions released from membranes to water under the dark condition were also analyzed using ICP-MS. To check if the releasing of loaded metal ions into water would deleteriously affect the metal weight ratios in the membrane, the amount of free ions coming off the $\mathrm{Cu}-\mathrm{Ag}-\mathrm{TiO}_{2}$ membrane was analyzed over a $10 \mathrm{~h}$ period. Water samples were collected every 20 min and analyzed through ICP-MS.

\section{Results and discussion}

\subsection{Membrane surface morphology and characterization}

The surface morphology of the nanowire membranes were analyzed by SEM and a uniform distribution of the $\mathrm{TiO}_{2}$ nanowires (length of around $5 \mu \mathrm{m}$ and diameter of tens of nanometers) with random orientation was observed on each membrane (Fig. 2). The nanowires were identified as anatase $\mathrm{TiO}_{2}$ (JCPDS No. 21-1272 [25]; Fig. S1, please see it in Supplementary material). The XRD analysis of the $\mathrm{Cu}-\mathrm{Ag}-\mathrm{TiO}_{2}$ composite was also performed but no peak of $\mathrm{Ag}$ or $\mathrm{Cu}$ was found, likely because of the low metal concentration and well dispersion of metals onto $\mathrm{TiO}_{2}$ surface [15]. The lack of high temperature treatment (photo-deposition of $\mathrm{Ag}$ and adsorption of $\mathrm{Cu}$, followed by air calcination at $375^{\circ} \mathrm{C}$ ) in the materials synthesis process makes it unlikely that $\mathrm{Ag}$ and $\mathrm{Cu}$ be incorporated into the $\mathrm{TiO}_{2}$ lattice (consistent with the literature $[15,26]$ ) and the metal particle surfaces may form silver oxides and copper oxides. Unfortunately, ICP-MS could not differentiate metal oxides from metals, and XPS or XRD could not give accurate information on the composition, crystal structure and chemical states of $\mathrm{Ag}$ or $\mathrm{Cu}$ because of their very low concentrations. Because the metal ion loaded membranes have a surface morphology similar to that of the $\mathrm{TiO}_{2}$ membrane (Figs. 2a-2b), only the SEM images of the $\mathrm{TiO}_{2}$ and the $\mathrm{Cu}-\mathrm{Ag}-\mathrm{TiO}_{2}$ membranes were given here. Although silver and copper on the membrane were not observed under SEM, the EDS analysis verified their presence (Figs. 2c-2e). Subsequent digestion of the silver and copper off the $\mathrm{TiO}_{2}$ nanowires with the ensuing analysis by ICP-MS confirmed the concentration was $2 \%$ for silver and 3\% for copper. The membrane cross-section image (with glassfiber substrate removed) is displayed in Fig. 2f. The membrane has a uniform thickness of $35 \pm 2$ $\mu \mathrm{m}$, thick enough to block the UV as the literature reported that the depth of UV penetration through $\mathrm{TiO}_{2}$ is only a few micrometers [27,28]. The light intensities across the membrane (without glassfiber substrate) were then measured using the ILT950 Spectroradiometer (Interna- tional Light Technologies, Inc., MA, USA) and were found to be fully shielded by the membrane; therefore, the photoreaction only occurred on membrane surface.

Membrane pore size distribution was characterized using the mercury porosimetry method. Results are displayed in Fig. 3 where the $y$-axis, $\mathrm{d} V / \mathrm{d} \log D$, is the specific mercury intrusion volume (V) versus the logarithm of pore diameter (D). As can be seen, all membranes have pore sizes peaked in the range of 4 to $8 \mu \mathrm{m}$. The $\mathrm{Cu}-\mathrm{Ag}-$ $\mathrm{TiO}_{2}$ membrane has relatively smaller pore volume (smaller $y$-axis value) over the entire pore size range thus less porous than other membranes. The pore suppression for the $\mathrm{Cu}-\mathrm{Ag}-\mathrm{TiO}_{2}$ membrane may be due to the loading of both copper and silver metals. Because the membrane pore sizes are much greater than the typical sizes of $E$. coli $(0.25-1 \mu \mathrm{m}$ in diameter and $2 \mu \mathrm{m}$ in length [29]) and bacteriophage MS2 (275 $\AA$ [30]), the microorganism rejection by each membrane via membrane filtration alone may not cause much difference. However, the large membrane pore size is beneficial to achieve a high pollutant (e.g., microorganisms, natural organic matters) removal at a low transmembrane pressure $(<300 \mathrm{kPa})$ when deposited with photocatalysts [31].

\subsection{Membrane performance for E. coli inactivation}

The removal of bacteria, E. coli, by the photocatalytic membranes under both dark and UV light conditions are shown in Fig. 4. Under the dark condition (Fig. 4a), removal of E. coli was mainly achieved via membrane retention. A decrease of bacteria inactivation was observed over time for all the membranes except the $\mathrm{Cu}-\mathrm{Ag}-\mathrm{TiO}_{2}$ membrane. The $\mathrm{Cu}-\mathrm{Ag}-\mathrm{TiO}_{2}$ membrane also shows the highest $E$. coli inactivation in most situations among all the membranes. Because the smaller membrane pore size (Fig. 2) may not be significant enough to cause such higher inactivation, the free silver and copper ions (released from the membrane) in the solution surrounding the membrane may be the reason [13], as metal ions on membrane photocatalyst are typically not bioavailable to kill bacteria [32]. In addition, a synergistic effect between silver and copper ions is likely present because only photo-depositing silver (the $\mathrm{Ag}-\mathrm{TiO}_{2}$ membrane) did not lead to better membrane performance and only loading copper (the $\mathrm{Cu}$ $\mathrm{TiO}_{2}$ membranes) led to worse performance comparing to the $\mathrm{TiO}_{2}$ membrane (Fig. 4a). The very high inactivation of E. coli at the beginning of the test using the $\mathrm{Ag}-\mathrm{TiO}_{2}$ membrane (consistent with [13]) is likely because of the high concentration of silver ions coming off the membrane (Fig. 5). This phenomenon together with the fact of an inconsistent trend between E. coli inactivation (Fig. 4a) and concentrations of free silver ions in water (Fig. 5) suggests the bactericidal property of silver ions may be most effective at the beginning of the test when the water surrounding the membrane has relatively high silver 

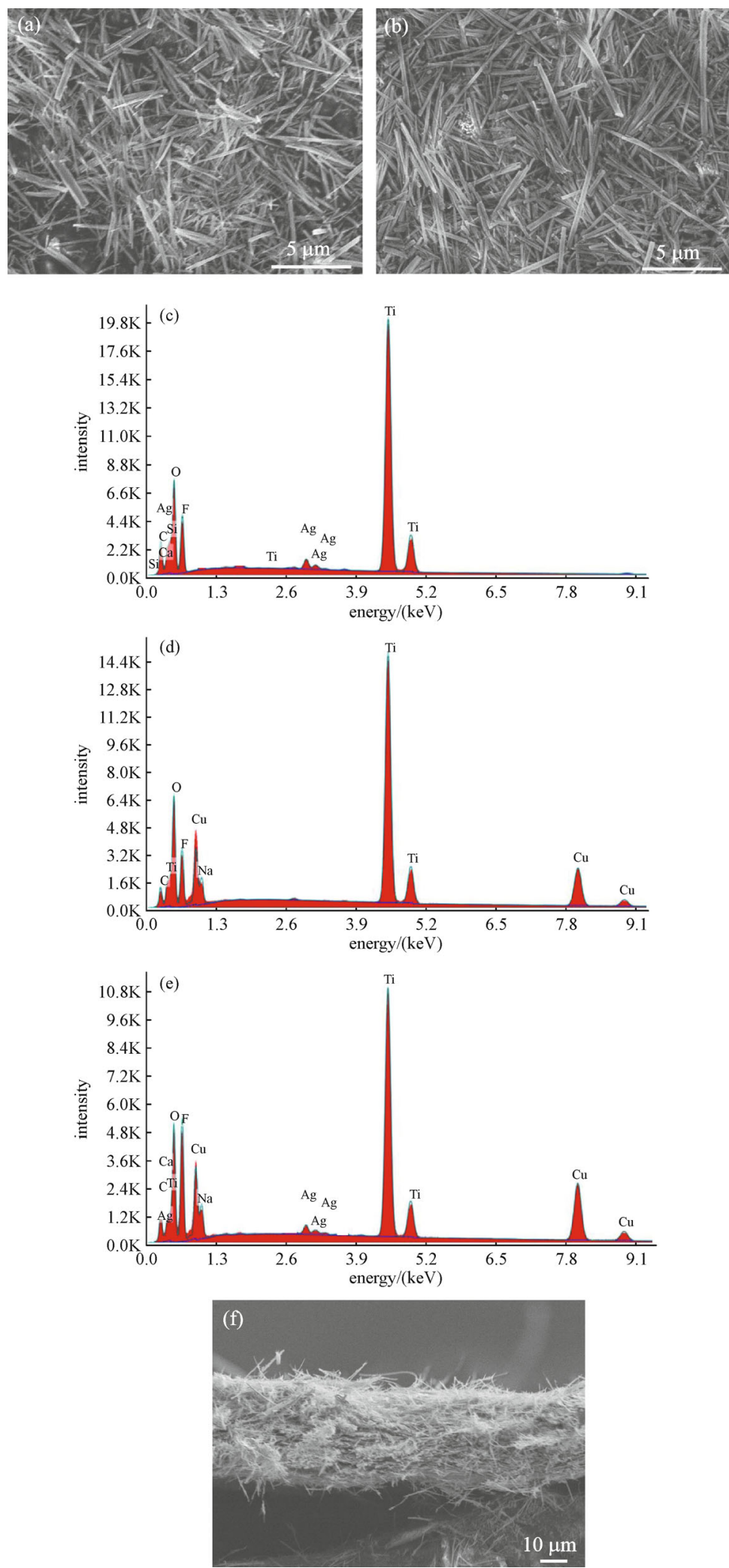

Fig. 2 SEM images of the $\mathrm{TiO}_{2}$ membrane (a) and the $\mathrm{Cu}-\mathrm{Ag}-\mathrm{TiO}_{2}$ membrane (b); EDS analysis results of the $\mathrm{Ag}-\mathrm{TiO}{ }_{2}$ membrane (c), the $\mathrm{Cu}-\mathrm{TiO}_{2}$ membrane (d) and the $\mathrm{Cu}-\mathrm{Ag}-\mathrm{TiO}_{2}$ membrane (e); and membrane cross-section (f) 


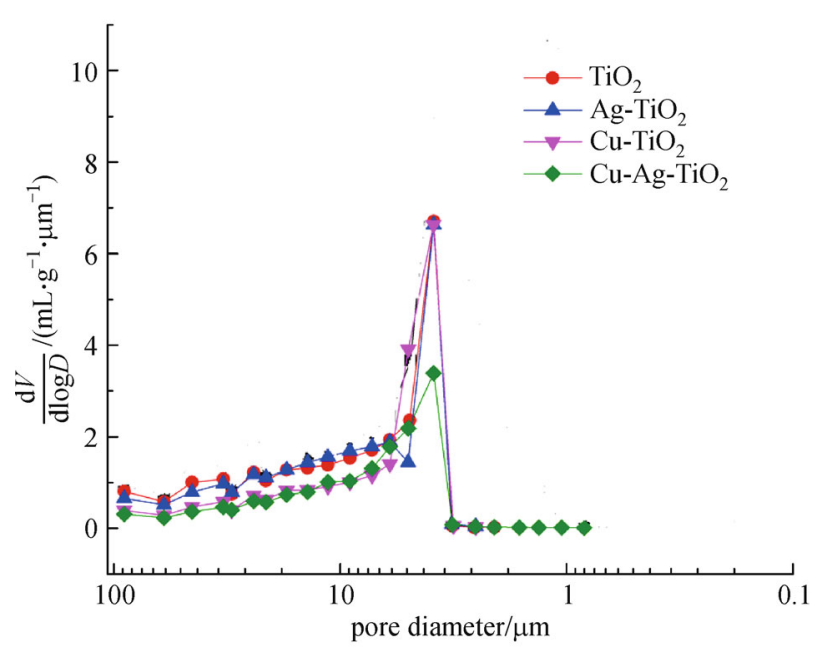

Fig. 3 Pore size distributions of the prepared membranes
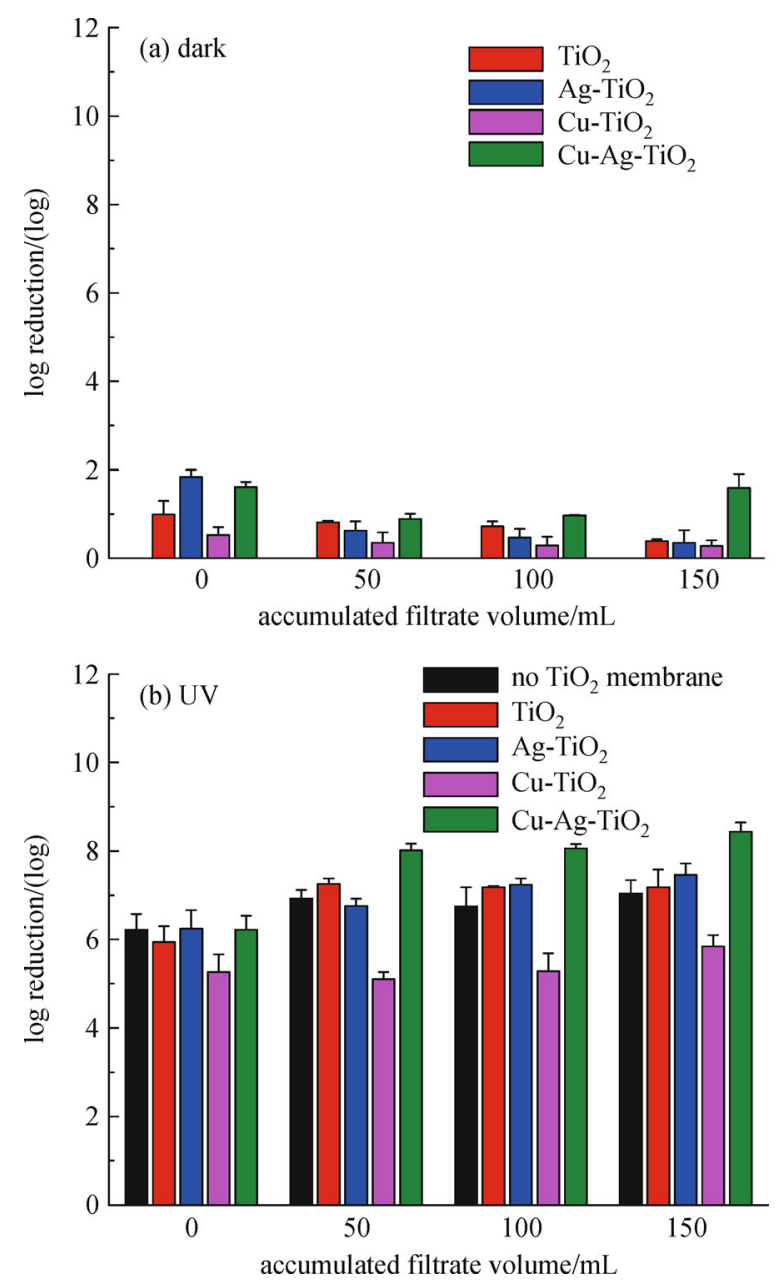

Fig. 4 Inactivation of $E$. coli by the $\mathrm{TiO}_{2}, \mathrm{Ag}-\mathrm{TiO}_{2}, \mathrm{Cu}-\mathrm{TiO}_{2}$, and $\mathrm{Cu}-\mathrm{Ag}-\mathrm{TiO}_{2}$ membranes under dark (a) and UV (b) conditions.

concentrations ( $\sim 10 \mathrm{ppb}$; Fig. 5). The unexpectedly poor performance of the $\mathrm{Cu}-\mathrm{TiO}_{2}$ membrane is likely because of

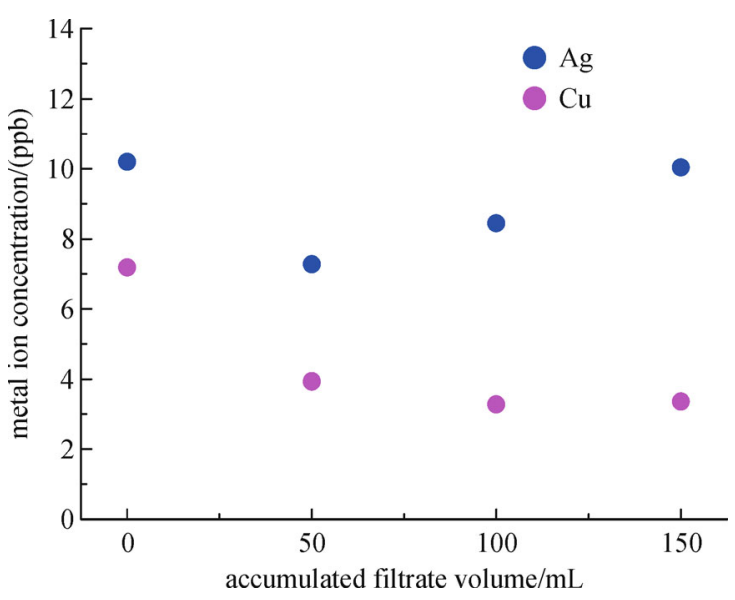

Fig. 5 Concentrations of free silver ions in water effluent for the $\mathrm{Ag}-\mathrm{TiO}_{2}$ membrane and copper ions for the $\mathrm{Cu}-\mathrm{TiO}_{2}$ membrane under the dark condition

copper ions in water facilitating the growth of E. coli, leading to a poor $E$. coli rejection. It was reported that copper was an essential trace element vital to the growth of microorganisms because of its ability to be incorporated into a variety of essential metabolic proteins and metalloenzymes, stimulating the immune system to fight infections, repair injured tissues, and promote healing $[33,34]$. The reason that copper benefits $E$. coli rather than poisoning it here may be due to its very low concentration ( $<10$ ppb by ICP-MS; Fig. 5). For comparison, copper (II) concentrations of 3.18 to $127 \mathrm{ppm}$ were studied for its toxicity to E. coli [10] and the inactivation was found to increase with higher copper content [16]. However, a high copper content may suppress the membrane photocatalytic activity if exposed to UV irradiation because it may form recombination centers of photo-induced charges [15]; therefore, there exists an optimal ratio of copper adsorbed onto the membrane.

The effectiveness of $E$. coli inactivation under UV irradiation was also studied and a significant higher inactivation was observed (Fig. 4b) than that under the dark condition (Fig. 4a). The $\mathrm{TiO}_{2}$ membrane showed slightly higher disinfection performances than that without $\mathrm{TiO}_{2}$ membrane (black column in Fig. 4b, UV only), and the $\mathrm{Cu}-\mathrm{Ag}-\mathrm{TiO}_{2}$ membrane showed much greater disinfection capability than that without membrane. The reason that UV disinfection is slightly higher than the $\mathrm{TiO}_{2}$ membrane (red column in Fig. 4b) at the beginning of the test is likely due to the membrane light shielding effect. The improved $\mathrm{TiO}_{2}$ membrane disinfection after $10 \mathrm{~min}$ (accumulated filtrate volume of $50 \mathrm{~mL}$ ) suggests a short $\left(\leqslant 10 \mathrm{~min}\right.$ ) activation time is needed for $\mathrm{TiO}_{2}$ to initiate photocatalytic disinfection. The $\mathrm{Ag}-\mathrm{TiO}_{2}$ membrane shows comparable or higher inactivation of $E$. coli in most cases than the $\mathrm{TiO}_{2}$ membrane; thus the improved membrane photocatalytic disinfection by photo-depositing silver may be demonstrated [15]. Similar to the dark 
condition, a poor performance of the $\mathrm{Cu}-\mathrm{TiO}_{2}$ membrane was observed, thus it is unclear if loading copper has increased the membrane photocatalytic activity (thus disinfection). Still, the $\mathrm{Cu}-\mathrm{Ag}-\mathrm{TiO}_{2}$ membrane shows the highest $E$. coli inactivation among all the membranes, although loading silver or copper alone did not significantly improve the inactivation. The possible reasons are: (1) the synergistic effect between free silver and copper ions in water for $E$. coli inactivation (as observed under the dark condition in Fig. 4a) and (2) the enhanced photocatalytic activity of $\mathrm{TiO}_{2}$ because of co-loading $\mathrm{Ag}$ and $\mathrm{Cu}$ on the membrane. An increase in photocatalytic activity due to combining silver and copper was also recently reported by Behnajady et al. for the removal of C. I. Acid Orange 7 as compared to $\mathrm{Ag}-\mathrm{TiO}_{2}$ nanoparticles and $\mathrm{Cu}-\mathrm{TiO}_{2}$ nanoparticles [15]. It should be noted that the bacteria removal of $7.68 \pm 0.99$ logs by the $\mathrm{Cu}-\mathrm{Ag}-\mathrm{TiO}_{2}$ membrane has largely exceeded the US EPA standard for bacteria inactivation, which requires a $6 \log$ removal of bacteria certified under the National Sanitation Foundation (NSF)/American National Standards Institute (ANSI) standard P231. Also, the free silver and copper ions in water (Fig. 5) have concentrations that are far below the US EPA maximum contaminant level of $100 \mathrm{ppb}$ for silver and $1300 \mathrm{ppb}$ for copper ions in drinking water [35].

\subsection{Membrane performance for bacteriophage MS2 inactivation}

For the virus experiments performed under the dark condition, removal of bacteriophage MS2 was achieved mainly via membrane retention and very little viruscidal inactivation was observed (Fig. 6a). Compared to the $\mathrm{TiO}_{2}$ membrane, the $\mathrm{Cu}-\mathrm{TiO}_{2}$ membrane shows a comparable performance for bacteriophage MS2 inactivation and the free copper ions in water has insignificant effect on membrane viruscidal activity. Therefore, the virus, bacteriophage MS2, may be less susceptible to copper ions in water than $E$. coli is at the current investigated concentration level. It can also be seen from Fig. 6a that the $\mathrm{Ag}-\mathrm{TiO}_{2}$ membrane always has higher inactivation than the $\mathrm{TiO}_{2}$ membrane, which is likely attributed to the free silver ions in water, thus bacteriophage MS2 is more susceptible to silver ions than E. coli is. Similar to the test for $E$. coli inactivation (Fig. 4a), a much higher bacteriophage MS2 inactivation was observed by the $\mathrm{Cu}-\mathrm{Ag}-\mathrm{TiO}_{2}$ membrane. Hence, a similar synergistic effect between copper and silver ions in the water filtration system as previously discussed for $E$. coli inactivation may have taken place for bacteriophage MS2 inactivation.

Membrane performance under UV light irradiation for bacteriophage MS2 inactivation is displayed in Fig. 6 b. Similar to E. coli, much higher disinfection of MS2 were observed than in dark condition likely due to the UV disinfection (black column in Fig. 6b) and the photo-
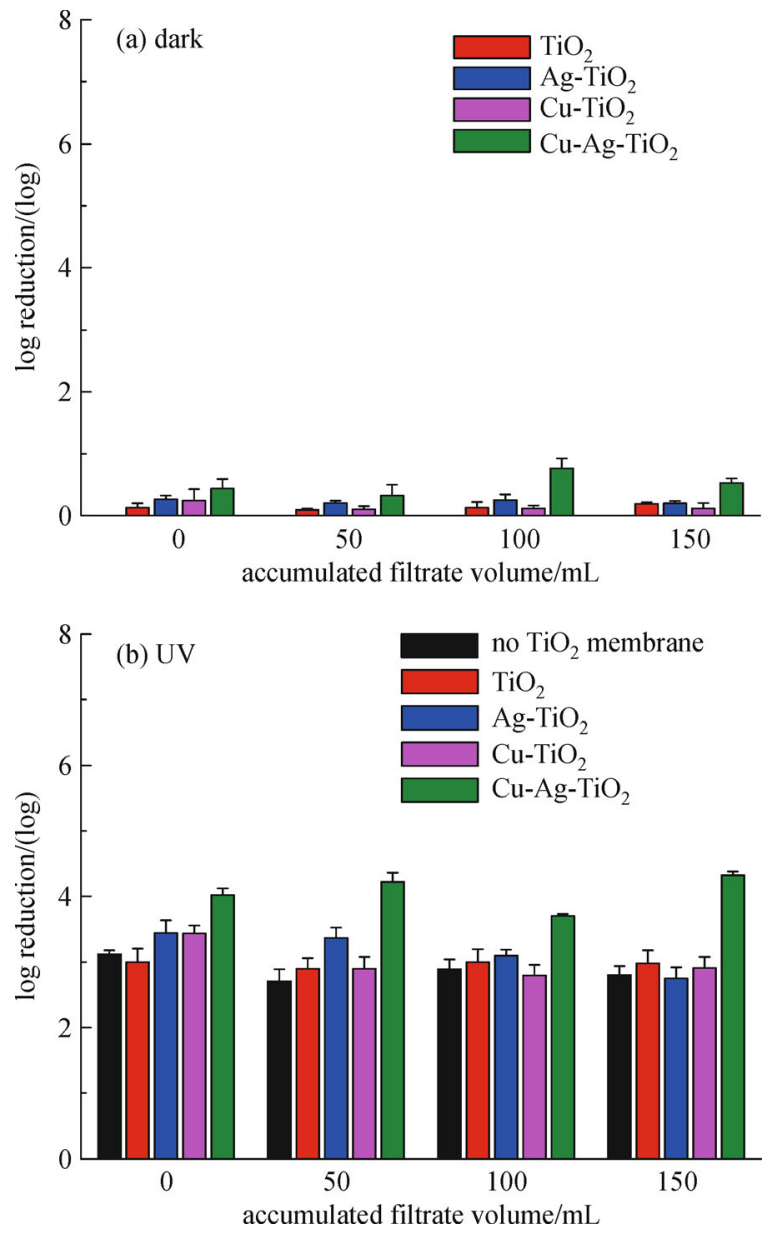

Fig. 6 Inactivation of bacteriophage $\mathrm{MS} 2$ for the $\mathrm{TiO}_{2}, \mathrm{Ag}-\mathrm{TiO}_{2}$, $\mathrm{Cu}-\mathrm{TiO}_{2}$, and $\mathrm{Cu}-\mathrm{Ag}-\mathrm{TiO}_{2}$ membranes under dark (a) and $\mathrm{UV}$ (b) conditions.

catalytic disinfection induced by the $\mathrm{TiO}_{2}$ photocatalyst materials. Still, the UV disinfection showed slightly higher performance than the $\mathrm{TiO}_{2}$ membrane at the beginning of the test likely due to the membrane light shielding effect. A slightly higher average inactivation by the $\mathrm{Ag}-\mathrm{TiO}_{2}$ membrane than by the $\mathrm{TiO}_{2}$ membrane was observed over the $30 \mathrm{~min}$ period. However, it is not clear whether the improved inactivation was due to the enhanced photocatalytic activity of $\mathrm{TiO}_{2}$ or due to the free silver ions in water (as demonstrated in the dark condition). The performance of the $\mathrm{Cu}-\mathrm{TiO}_{2}$ membrane did not have significant difference from the $\mathrm{TiO}_{2}$ membrane. The inactivation by the $\mathrm{Cu}-\mathrm{Ag}-\mathrm{TiO}_{2}$ membrane is significantly higher than the other membranes under UV. The synergy effect of free silver and copper ions in water (as demonstrated under the dark condition in Fig. 6a) could not contribute to such a high inactivation. Thus, the enhanced photocatalytic effect of $\mathrm{TiO}_{2}$ due to co-loading $\mathrm{Ag}$ and $\mathrm{Cu}$ should have made contribution to the overall high inactivation. It should be noted that the virus removal of $4.06 \pm 0.27 \log$ by the $\mathrm{Cu}-\mathrm{Ag}-\mathrm{TiO}_{2}$ membrane has 
almost reached the US EPA standard for virus inactivation, which requires a $4 \log$ removal of virus certified under the National Sanitation Foundation (NSF)/American National Standards Institute (ANSI) standard P231.

3.4 Effect of metal releasing on metal atomic ratio in the membrane

Over a $10 \mathrm{~h}$ test, both silver and copper ions were detected in the water effluent, suggesting a continuing releasing of metal ions from membrane into water thus a gradual decrease of the metal atomic ratio on the membrane. At the end of the test, the amount of silver and copper released into water accounted for only $0.16 \%$ and $0.02 \%$, respectively, of the original amount loaded on the membrane, indicating the metals are stable on $\mathrm{TiO}_{2}$ surface. At this release rate, it would take thousands of hours to completely deplete the silver and copper, longer than a typical membrane lifetime. In addition, the minimal change in metal concentration would not cause dramatic change of membrane performances for microorganism inactivation over a long period.

\section{Conclusions}

This study fabricated a silver and copper loaded $\mathrm{TiO}_{2}$ nanowire membrane that shows enhanced photo-activated disinfection of bacteria and virus from drinking water. During a 30 min test, the $E$. coli removal by the $\mathrm{Cu}-\mathrm{Ag}$ $\mathrm{TiO}_{2}$ membrane largely exceeded the US EPA standard and the virus removal almost met the standard. Although metals were released from the membrane into the water, the ion concentration in the water effluent are far below the US EPA MCL for silver and copper ions in drinking water. The enhanced photo-activated disinfection by the $\mathrm{Cu}-\mathrm{Ag}-\mathrm{TiO}_{2}$ membrane was attributed to the synergistic effect between the free silver and copper ions in water and the synergies of the loaded metal ions on the membrane that have enhanced the membrane photocatalytic activity. Contribution of each effect on the improvement of microorganism disinfection needs to be investigated in future.

Acknowledgements The authors acknowledge A. O. Smith Corporation for providing biologic samples and for its financial support.

Electronic Supplementary Material Supplementary material is available in the online version of this article at http://dx.doi.org/10.1007/s11783-0160854-x and is accessible for authorized users.

\section{References}

1. Murray K E, Manitou-Alvarez E I, Inniss E C, Healy F G, Bodour A A. Assessment of oxidative and UV-C treatments for inactivating bacterial biofilms from groundwater wells. Frontiers of Environ- mental Science \& Engineering, 2015, 9(1): 39-49

2. Pablos C, Marugán J, van Grieken R, Serrano E. Emerging micropollutant oxidation during disinfection processes using UVC, UV-C/ $\mathrm{H}_{2} \mathrm{O}_{2}, \mathrm{UV}-\mathrm{A} / \mathrm{TiO}_{2}$ and $\mathrm{UV}-\mathrm{A} / \mathrm{TiO}_{2} / \mathrm{H}_{2} \mathrm{O}_{2}$. Water Research, 2013, 47(3): 1237-1245

3. Ollis D F. Photocatalytic purification and remediation of contaminated air and water. Comptes Rendus de l'Académie des Sciences Series IIC: Chemistry, 2000, 3(6): 405-411

4. Thabet S, Weiss-Gayet M, Dappozze F, Cotton P, Guillard C. Photocatalysis on yeast cells: toward targets and mechanisms. Applied Catalysis B: Environmental, 2013, 140-141: 169-178

5. Chen X, Mao S S. Titanium dioxide nanomaterials: synthesis, properties, modifications, and applications. Chemical Reviews, 2007, 107(7): 2891-2959

6. Wang S, Wang K, Jehng J, Liu L. Preparation of $\mathrm{TiO}_{2} / \mathrm{MCM}-41$ by plasma enhanced chemical vapor deposition method and its photocatalytic activity. Frontiers of Environmental Science \& Engineering, 2012, 6(3): 304-312

7. Coleman H M, Marquis C P, Scott J A, Chin S S, Amal R. Bactericidal effects of titanium dioxide-based photocatalysts. Chemical Engineering Journal, 2005, 113(1): 55-63

8. Li Q, Mahendra S, Lyon D Y, Brunet L, Liga M V, Li D, Alvarez P J J. Antimicrobial nanomaterials for water disinfection and microbial control: potential applications and implications. Water Research, 2008, 42(18): 4591-4602

9. Ashkarran A A, Aghigh S M, Kavianipour M, Farahani N J. Visible light photo-and bioactivity of $\mathrm{Ag} / \mathrm{TiO}_{2}$ nanocomposite with various silver contents. Current Applied Physics, 2011, 11(4): 1048-1055

10. Selvaraj S, Saha K C, Chakraborty A, Bhattacharyya S N, Saha A. Toxicity of free and various aminocarboxylic ligands sequestered copper(II) ions to Escherichia coli. Journal of Hazardous Materials, 2009, 166(2-3): 1403-1409

11. Khraisheh M, Wu L, Al-Muhtaseb A H, Al-Ghouti M A. Photocatalytic disinfection of Escherichia coli using $\mathrm{TiO}_{2}-\mathrm{P} 25$ and $\mathrm{Cu}$-doped $\mathrm{TiO}_{2}$. Chemical Engineering Journal, 2005, 113: 5563

12. McEvoy J G, Zhang Z. Review: antimicrobial and photocatalytic disinfection mechanisms in silver-modified photocatalysts under dark and light conditions. Journal of Photochemistry and Photobiology C, Photochemistry Reviews, 2014, 19: 62-75

13. Liga M V, Bryant E L, Colvin V L, Li Q. Virus inactivation by silver doped titanium dioxide nanoparticles for drinking water treatment. Water Research, 2011, 45(2): 535-544

14. Hernández-Gordillo A, González V R. Silver nanoparticles loaded on $\mathrm{Cu}$-doped $\mathrm{TiO}_{2}$ for the effective reduction of nitro-aromatic contaminants. Chemical Engineering Journal, 2015, 261: 53-59

15. Behnajady M A, Eskandarloo H. Silver and copper co-impregnated onto $\mathrm{TiO}_{2}-\mathrm{P} 25$ nanoparticles and its photocatalytic activity. Chemical Engineering Journal, 2013, 228: 1207-1213

16. Fang J, Liu H, Shang C, Zeng M, Ni M, Liu W. E. coli and bacteriophage MS2 disinfection by UV, ozone and the combined UV and ozone processes. Frontiers of Environmental Science \& Engineering, 2014, 8(4): 547-552

17. Anastasi E M, Wohlsen T D, Stratton H M, Katouli M. Survival of Escherichia coli in two sewage treatment plants using UV irradiation and chlorination for disinfection. Water Research, 
2013, 47(17): 6670-6679

18. Vélez-Colmenares J J, Acevedo A, Nebot E. Effect of recirculation and initial concentration of microorganisms on the disinfection kinetics of Escherichia coli. Desalination, 2011, 280(1-3): 20-26

19. Venieri D, Gounaki I, Binas V, Zachopoulos A, Kiriakidis G, Mantzavinos D. Inactivation of MS2 coliphage in sewage by solar photocatalysis using metal-doped $\mathrm{TiO}_{2}$. Applied Catalysis B: Environmental, 2015, 178: 54-64

20. Sigstam T, Rohatschek A, Zhong Q, Brennecke M, Kohn T. On the cause of the tailing phenomenon during virus disinfection by chlorine dioxide. Water Research, 2014, 48: 82-89

21. Zhang Q, Rao G, Rogers J, Zhao C, Liu L, Li Y. Novel anti-fouling $\mathrm{Fe}_{2} \mathrm{O}_{3} / \mathrm{TiO}_{2}$ nanowire membranes for humic acid removal from water. Chemical Engineering Journal, 2015, 271: 180-187

22. Li M, Noriega-Trevino M E, Nino-Martinez N, Marambio-Jones C, Wang J, Damoiseaux R, Ruiz F, Hoek E M V. Synergistic bactericidal activity of $\mathrm{Ag}-\mathrm{TiO}_{2}$ nanoparticles in both light and dark conditions. Environmental Science \& Technology, 2011, 45(20): 8989-8995

23. Yadav H M, Otari S V, Koli V B, Mali S S, Hong C K, Pawar S H, Delekar S D. Preparation and characterization of copper-doped anatase $\mathrm{TiO}_{2}$ nanoparticles with visible light photocatalytic antibacterial activity. Journal of Photochemistry and Photobiology A Chemistry, 2014, 280: 32-38

24. Giesche H. Mercury porosimetry: a general (practical) overview. Particle \& Particle Systems Characterization, 2006, 23(1): 1-11

25. Lynch C T. CRC Handbook of Materials Science, Volume II: Material Composites and Refractory Materials. Florida: CRC Press, 1975.

26. Li J, Xu J, Dai W, Fan K. Dependence of Ag deposition methods on the photocatalytic activity and surface state of $\mathrm{TiO}_{2}$ with twistlike helix structure. Journal of Physical Chemistry C, 2009, 113(19): 8343-8349
27. Zhang J, Wang J, Zhao Z, Yu T, Feng J, Yuan Y, Tang Z, Liu Y, Li $\mathrm{Z}$, Zou Z. Reconstruction of the (001) surface of $\mathrm{TiO}_{2}$ nanosheets induced by the fluorine-surfactant removal process under UVirradiation for dye-sensitized solar cells. Physical Chemistry Chemical Physics, 2012, 14(14): 4763-4769

28. Carbonell E, Ramiro-Manzano F, Rodríguez I, Corma A, Meseguer F, García H. Enhancement of $\mathrm{TiO}_{2}$ photocatalytic activity by structuring the photocatalyst film as photonic sponge. Photochemical \& Photobiological Sciences, 2008, 7(8): 931-935

29. Kubitschek H E. Cell volume increase in Escherichia coli after shifts to richer media. Journal of Bacteriology, 1990, 172(1): 94-101

30. Stockley P G, Stonehouse N J, Valegård K. Molecular mechanism of RNA phage morphogenesis. International Journal of Biochemistry, 1994, 26(10-11): 1249-1260

31. Zhang X, Du A J, Lee P, Sun D D, Leckie J O. $\mathrm{TiO}_{2}$ nanowire membrane for concurrent filtration and photocatalytic oxidation of humic acid in water. Journal of Membrane Science, 2008, 313(1-2): $44-51$

32. Zodrow K, Brunet L, Mahendra S, Li D, Zhang A, Li Q, Alvarez P J J. Polysulfone ultrafiltration membranes impregnated with silver nanoparticles show improved biofouling resistance and virus removal. Water Research, 2009, 43(3): 715-723

33. Kaitainen S, Mähönen A J, Lappalainen R, Kröger H, Lammi M J, $\mathrm{Qu}$ C. $\mathrm{TiO}_{2}$ coating promotes human mesenchymal stem cell proliferation without the loss of their capacity for chondrogenic differentiation. Biofabrication, 2013, 5(2): 025009

34. Chen S, Guo Y, Zhong H, Chen S, Li J, Ge Z, Tang J. Synergistic antibacterial mechanism and coating application of copper/titanium dioxide nanoparticles. Chemical Engineering Journal, 2014, 256: 238-246

35. United States Environmental Protection Agency. Retrieved from: http://water.epa.gov/drink/contaminants/index.cfm (accessed November 25, 2015) 